\title{
Koroner Arter Hastalığı Olan Köpeklerde Hipertansiyonun İnflamatuar Etkisinin Ekokardiyografi ile Değerlendirilmesi
}

\author{
Mehmet İRIADAM ${ }^{1, a, *}$, Melahat TOKER ${ }^{2, b}$ \\ ${ }^{1}$ Harran Üniversitesi Veteriner Fakültesi Fizyoloji Anabilim Dalı Eyyübiye Yerleşkesi, Şanlıurfa. \\ ${ }^{2}$ Ankara Eğitim ve Araştırma Hastanesi Kardiyoloji Kliniği. Ankara. \\ aORCID: ORCID 0000-0002-9694-6014, bORCID: 0000-0001-5442-4309
}

\begin{abstract}
Geliș Tarihi: 05.05.2020
Kabul Tarihi: 10.09.2020

Özet: Bu çalışma; koroner arter hastalığı (KAH) bulunan köpeklerde hipertansiyonun oluşturduğu (HT) inflamatuvar süreci üzerine olası etkilerini belirlemek üzere yapılmıştır. Ankara ilindeki özel pet kliniklerine gelen, farklı yaş, kilo, cins ve ırklardaki toplam 25 köpek üzerinde yürütüldü. Hayvanlara elektrokardiyografi, tansiyon, telegrafi, tam kan ve C- reaktif protein (CRP) ölçümleri yapıldı. Ekokardiyografilerinde ise 2D, M-mod, ve renkli Doppler ekokardiyografi yöntemleri kullanılarak, sol ventrikül sistol ve diyastol çapları, ventrikül duvar kalınlıkları, ventrikül duvar hareketlerindeki anormallikler ile kapak patolojileri değerlendirildi. Hayvanların ekokardiyografilerinde sol ventrikül konsantrik hipertrofi (LVH) ve diastolik diskfonksiyonu tespit edildi. Ayrıca; Ekokardiyografide Mitral kapak tutulumları ile kapakçıklar üzerinde anüler kalsifikasyon izlendi. İnterventriküler septum kalınlığında önemli ölçüdeki artışlarla beraber sol ventrikül arka duvar kalınlığında bir artış belirlendi. Bununla birlikte; yüksek olan CRP ve kolestrol değerlerinde ise anlamlı bir artış belirlendi. Yapılan rutin ekokardiyografilerde parasternal uzun eksende $M$ mode tekniği ile sol ventrikül diastolik ve sistolik çapları $(\mathrm{cm})$, interventriküler septum çapı $(\mathrm{cm})$, posterior duvar kalınlığı $(\mathrm{cm})$, ejeksiyon fraksiyon (\%), fraksiyon kısalma (\%), aort çapı $(\mathrm{cm})$ ve sol atriyum $(\mathrm{cm})$ ölçüldü. Parasternal kısa eksende mitral kapağın yapısı, segmenter duvar hareket bozukluğu, pulmoner arter çapı ve pulmoner kapak değerlendirildi. Apikal boşluklarda 2,3,4 ve 5 boşlukları atriyoventriküler kapakları (mitral-triküspit kapak) ve semilunar kapak (aort kapak) değerlendirildi. İnflamasyonun sürecinin artışı, damarlarda oluşan kolestrol plaklarını da tetikleyebileceği ya/ya da daha fazla pıhtı yaratabileceği şeklindedir. Hipertansiyonun kardiyovasküler hastalıklar için önemli risk faktörlerinden hem morbidite hem de mortaliteyi önemli ölçüde arttırdığı şeklinde düşünülmektedir. Bütün bu değerlendirmelerimiz de ekokardiyografi, sol ventrikül hipertansiyonun tanısında elektrokardiyografinin yanı sıra vazgeçilemez bir tanı yöntemi olarak karşımıza çıkmaktadır
\end{abstract}

Anahtar Kelime: Ekokardiyografi, Köpek, Inflamation, Sol ventrikül.

\section{Evaluation of Inflammatory Effect of Hypertension by Echocardiography in Dogs with Coronary Artery Disease}

Abstract: The present investigation was performed to determine the possible effects of hypertension-induced (HT) inflammatory process in dogs with coronary artery disease (CAD). It was carried out on 25 dogs of different ages, weights, and breeds coming to private clinics in Ankara. Electrocardiography, Blood Pressure, Telegraphy, whole blood, and CReactive protein (CRP) measurements were performed on the animals. In the echocardiography, 2D, M-Mode, and color doppler methods were used to evaluate left ventricular systole and diastole diameters, ventricular wall thickness abnormalities in ventricular wall movement, and valve pathologies. Left ventricular concentric hypertrophy (LVH) and diastolic dysfunction were detected in echocardiographies of animals. In echocardiography anular calcification was observed on the valves and mitral valve involvement also. However, an increase in left ventricular posterior wall thickness was determined and significant increases in ventricular septum thickness. Although high increase CRP and cholesterol values were determined. The routine echocardiography, left ventricular diastolic and systolic diameters $(\mathrm{cm})$, interventricular septum diameter $(\mathrm{cm})$, posterior wall thickness $(\mathrm{cm})$, ejection fraction(\%), fraction shortening(\%), aortic diameter $(\mathrm{cm})$, and the left atrium $(\mathrm{cm})$ with $\mathrm{M}$ mode technique on long axis were measured. The structure of the mitral valve, segmental wall motion disorder, pulmonary artery diameter, and pulmonary valve were evaluated in the parasternal short axis. Atrioventricular valves (mitral-tricuspid valve) and half-moon valve (aortic valve) in the apical 2,3,4, and 5 spaces were evaluated. The increase of the inflammation process is that it may also trigger cholesterol plaques formed in the vessels and / or create more clots. It is thought that hypertension significantly increases both morbidity and mortality, which are important risk factors for cardiovascular diseases. In addition to the defined electrocardiography of left ventricular hypertension, echocardiography appears as an indispensable diagnostic method.

Keyword: Dog, Echocardiography, Left ventricule, Inflammation. 


\section{Giriş}

Bugün ülkemizde ve dünyada ateroskleroza bağı ölümlerin nedenler arasında ilk sırada yer aldığ bildirilmektedir (Gordon ve Kannel, 1971). Aterosklerotik plak, birçok yönüyle kronik inflamasyona benzemektedir. Inflamasyonun aterosklerotik olayının ilerlemesi ve trombotik komplikasyonların gelişmesine kadar her evrede rolü belirlenmiştir. Koroner arter hastalığı (KAH) kalp kasını besleyen ve koroner arterler olarak adlandırılan atardamarların daralma veya tıkanması sonucu kan akımının kısmen ya/ yada tamamen kesilmesine bağlı olarak ortaya çıkan bozukluklar olarak tanımlanmaktadır. Sebebi olarak ta damar sertliği olarak bilinen "ateroskleroz" olduğu görüşü hakimdir. Bu hastalığın en önemli özelliği ileri dönmelerde hayatı tehdit edebilen kalp krizine yol açabilmesidir (Felmeden ve ark., 2003; Gordon ve Kannel, 1971; Martinez ve ark.,1985). Hipertansiyon, koroner arter hastalığı için büyük bir risk faktörü olduğundan çoğunlukla $\mathrm{KAH}$ ile birlikte görülebilmektedir. Gerek sistolik gerekse diyastolik kan basınçlarındaki artışların KAH riskini arttırdığını gösteren ve epidemiyolojik çalışmalara dayanan çok sayıda bildirimler bulunmaktadır. Hipertansiyon koroner aterosklerozun gelişimini hızlandırmakta, koroner aterosklerozu gelişmiş hastalarda ise miyokardın oksijen ihtiyacı daha da arttırmaktadır. Hipertansiyona bağı olarak sol ventrikül hipertrofisinin gelişmesi durumunda koroner dolaşımda bazı bozukluklar meydana gelmektedir (Sieg-Dobrescu ve ark., 2001). Miyokard dokusunun artmasına bağlı olarak ekstravasküler koroner dirençte artmakta olup, bunun sonucunda da Koroner Mikrodolaşımın gelişmesi de sol ventrikül kitle artışının oldukça gerisinde kalmaktadır. Koroner direnç damarlarının tonusun da fonksiyonel bir artışa yol açarak koroner rezervi azaltmaktadır. Bütün bu nedenlere bağlı olarak hipertansif hastalarda özellikle sol ventrikül hipertrofisi de varsa iskeminin daha da arttığı görülmektedir. Sol ventrikül hipertrofisi olan bir hasta miyokard infarktüsü (MI) geçirecek olursa, MI daha yaygın olmakta ve infarktın ilerleme hızı daha da artmaktadır (Hingorani ve ark.,2000; Maat ve ark.,2002). Hasta infarktüs geçirirken antihipertansif tedavi alırsa bu akselerdeki değişiklikler kısmen de olsa önlenebilmektedir. Yine hipertansif hastalarda iskemiye yanıt olarak elektrofizyolojik bozukluklarda daha fazla artış ve ani ölüm görülmektedir. Koroner arter hastalığının hipertansiyonla birlikte bulunması durumunda bağlı morbidite ve mortalite oranları belirgin ölçüde yükselmektedir. Kan basıncı ile KAH arasındaki ilişki pozitif bir ilişki göstermekte hipertansif sayılmayacak değerlerde başlamaktadır.
$\mathrm{Bu}$ araştırmadaki temel amacımız stabil KAH'da hipertansiyonun inflamatuvar sürece üzerine ilave katkısının olup olmadığını belirlemektir.

\section{Materyal ve Metot}

Çalışmamız 2004 -2019 yılları arasında Ankara ilinde özel pet kliniklerine gelen, farklı yaş, kilo, cins ve ırklarda olan toplam 25 köpek üzerinde yürütüldü. Çalışmamızda etik kurul belgesine gerek bulunmamaktadır. Kliniğe gelen hasta hayvanlarda solunum güçlüğü, kalp atım sayısında artış, efor kapasitelerinde azalma, öksürük ve halsizlik gibi semptomlar belirlendi. Köpeklerin yaş ortalamaları $(7+/-2)$ arasında değişmekteydi. Hasta hayvanlara fiziksel muayeneden sonra Elektrokardiyografi, tansiyon, telegrafi, kan ve biyokimyasal parametreleri belirlemenin yanı sıra kardiak enzimlere bakıldı. Kan örneklerinin alınması 12 saat aç olarak bekletilen hayvanlardan beş dakika dinlendirildikten sonra gerçekleştirildi.

Tüm hayvanların transtorasik ekokardiyografileri AU5, HP Sonos 5500 cihazı ile yapıldı. Ayıca; bu hayvanlarda Mitsubishi highperformance digital color Printer sistem ile fotoğrafları çekildi. Ekokardiyografi'de ise 2D, Mmod, Doppler ve renkli Doppler ekokardiyografi yöntemleri kullanılarak, rutin olarak yapılan parasternal uzun eksen, parasternal kısa eksen, modifiye kesit ve apikal kesitlerle sol ventrikül sistol ve diyastol çapları, ventrikül duvar kalınlıkları, ventrikül duvar hareketlerindeki anomaliler ile kapak patolojileri değerlendirildi (Fu, 1995; Martinez ve ark., 1985; Renaudin ve ark., 1995).

\section{Bulgular}

Hayvanlarda iki boyutlu, M mode ve Doppler ekokardiyografide sol ventrikül konsantrik hipertrofi (LVH) ve diastolik diskfonksiyonu tespit edildi. Mitral kapakta CRP 'lerin yüksek olmasına bağlı olarak kapakçık tutulumları ve kapacıklar üzerinde anüler kalsifikasyon izlendi. Ayrıca; interventriküler septumda anlamlı artışlarla beraber sol ventrikül arka duvarda da artış izlendi.

Özellikle köpeklerde elektrokardiyografisi anlamlı olan her hastaya tansiyon bakıldı.

Hipertansiyon hastalarında özellikle kilolu, ileri yaş ve bazı ırklarda diyastolik disfonkiyon çoğunlukla izlendi.

Sistolik kan basıncı değerleri 150-180/mm Hg, diastolik kan basınç değerleri ise $90-110 / \mathrm{mm} \mathrm{Hg}$ arasında değişen aralıklarda belirlenerek hipertansiyon tespit edildi. Alınan kan örneklerinde 
total kolestorel, trigliserid ve glukoz değerlerinde önemli ölçüde arış olduğu tespit edildi. Ayrıca; $\mathrm{KAH}+\mathrm{HT}$ olan köpeklerde C-reaktif protein değerinde de önemli ölçüde artmış olduğu belirlendi. Koroner arter hastalığı olan hastalarda özellikle anterior, inferior segmentlerde ve/ veya diğer duvar hareket bozukluğu izlendi.

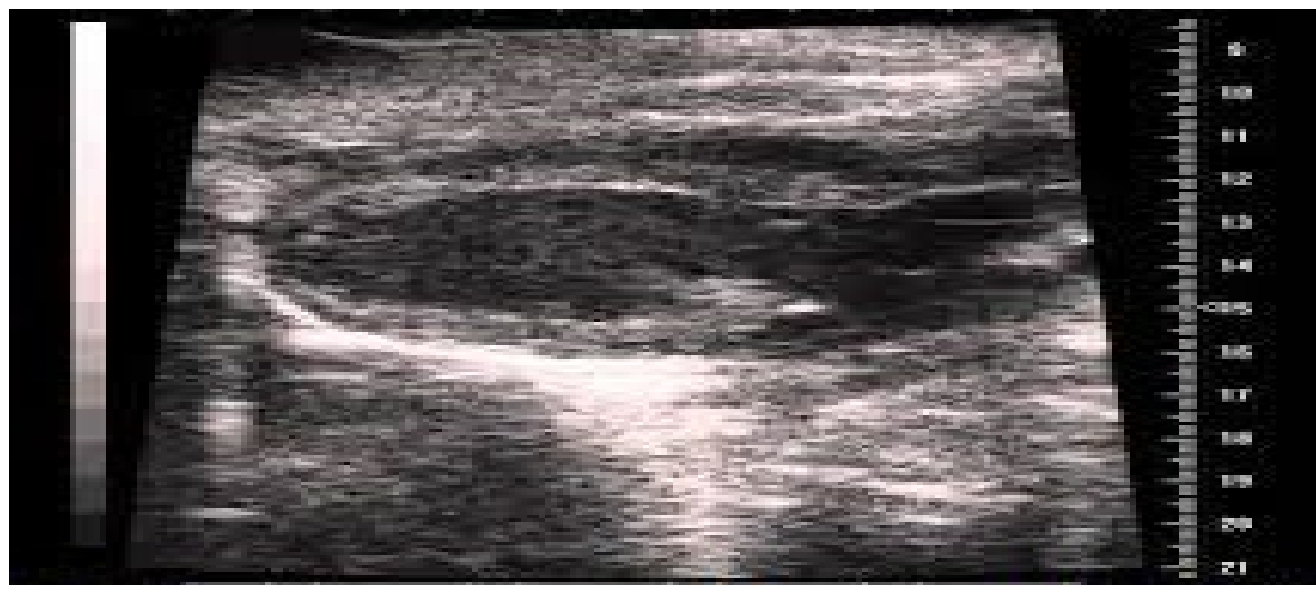

Şekil 1. Köpeklerde, parasternal uzun eksende hipertansiyona bağlı olarak hipertrofik görüntü

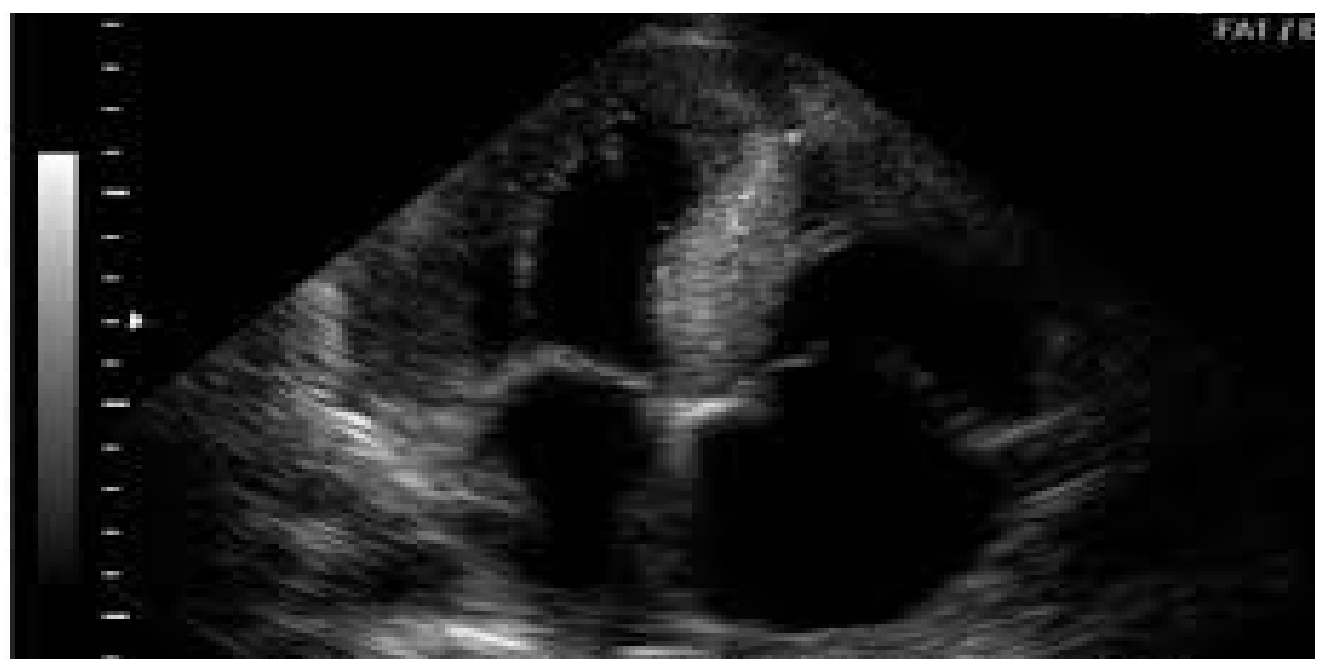

Şekil 2. Apikal dört boşluk görüntüsünde, sol ventrikül konsantrik hipertrofi (LVH)

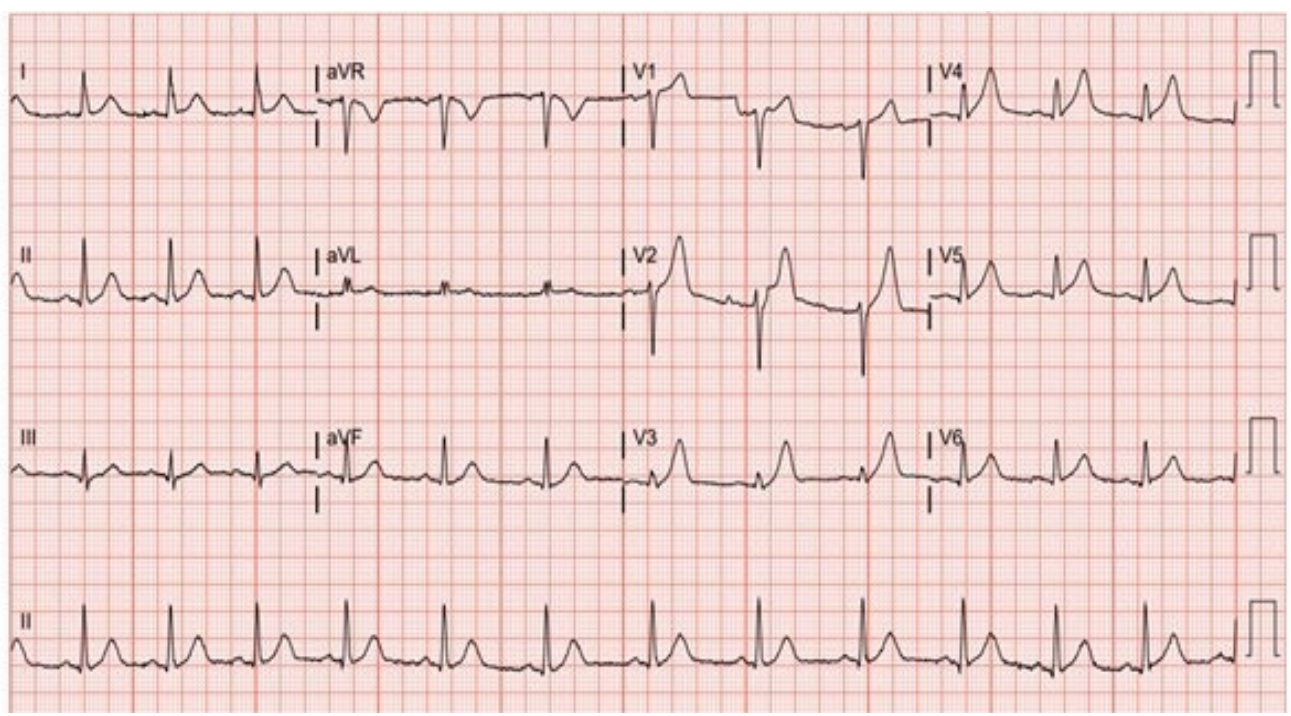

Şekil 3. Koroner arter hastalığında elektrokardiyografi 


\section{Tartışma ve Sonuç}

Hipertansiyon kardiyovasküler hastalıklar için en önemli risk faktörlerinden birisi olup, kardiyovasküler morbidite ve mortaliteyi belirgin oranda arttırmaktadır. Bu çalışmada, sadece koroner arter hastalığı olanların yanı sıra koroner arter hastalığı+HT olanlarda da inflamasyonun göstergesi olan CRP değerleri daha yüksek olduğu tespit edilmiştir. Fakat; $\mathrm{KAH}$ ve $\mathrm{KAH}+\mathrm{HT}$ olanlar kendi aralarında karşılaştırıldığında, $\mathrm{KAH}+\mathrm{HT}$ olanlarda inflamatuvar markerlarda anlamlı olarak farklılık bulunamadığı bunun da, (Renaudin ve ark. 1995; Mc Eniery ve Wilkinson 2005) bildirimleri ile paralellik göstermektedir.

Aterosklerotik olayın başlangıcından ilerlemesi ve trombotik komplikasyonların gelişmesine kadar kronik inflamasyon varlığı arasında bir ilişki gösterilmiş olup, bu konuda ki bulgularımızla uyum göstermektedir (Bhagat ve ark., 1996; Chrysohoou ve ark., 2004; Higashi ve ark.,2002). Inflamasyonun, $\mathrm{HT}^{\prime}$ nin sebebi mi yoksa sonucu mu olduğu kesin olarak bilinememektedir. Ancak; şu iyi bilinmektedir ki, belli endotelyal fonksiyon anormallikleri HT'e yol açabilmekte ve HT'nin kendisi de endotelyal fonksiyonları negatif yönde değiştirebilmektedir (Chung ve ark., 2004; Felmeden ve ark., 2003). Daha önceleri yumuşak fiziksel bir bariyer olarak bilinen adventisya, artık $\mathrm{HT}^{\prime}$ in fizyopatolojisine önemli role sahip serbest oksijen radikalleri için önemli kaynak olduğu bilinmektedir (Sieg ve ark., 2001). Hipertansif farelerin adventisyalarında arttmış sayıda inflamasyon hücreleri belirlendiği (Renaudin ve ark., 1995), aynı zamanda hipertansif fare modellerinde artarak aktive olan lenfosit ve monositlerin endotelyal hücrelere yapıştığı kanıtlanmıştır. Son yıllarda ateroskleroz ile inflamasyon arasındaki ilişkinin net olarak aydınlatılması, dolaşımdaki bazı inflamatuvar göstergelerinin kardiyovasküler olay gelişme riskini belirlemede yol gösterici olarak kullanılabileceği düşüncesini doğurmuştur. Bu belirteçler arasında en yoğun kanıtlar CRP ile ilişkili olanıdır. Yüksek ve orta derecedeki CRP değerleri, diğer risk faktörlerinin varlığından bağımsız olarak artmış kardiyovasküler olay riskine eşlik etmektedir (Chang ve ark.,1994; $\mathrm{Fu}, 1995)$. CRP'nin inflamatuar reaksiyonda birçok olayı aktive ettiği in vitro çalışmalar ile gösterilmiştir. CRP'nin kardiyovasküler hastalık riskini saptamadaki yeri diğer inflamatuvar göstergelere göre daha belirgindir (Gage ve ark., 1986; Gordon ve ark., 1971). Akut Miyokard infarktüs sonrasında ve unstabil angina pektoris esnasındaki yüksek CRP değerlerinin daha kötü sonuçları yansıttığı bilinmektedir. Esansiyel $\mathrm{HT}^{\prime}$ lu hastalarda sağlıklı kontrollere kıyasla CRP'nin yüksek olduğu gösterilmiştir (Okamura ve ark., 2004). Ayrıca; son zamanlarda ki birçok bildirimde pre-HT evresindeki hastaların, normotansif deneklerle karşılaştırıldığında, daha yüksek CRP seviyelerinin varlığı gösterilmiştir. Bu sonuçlar inflamasyon/HT ilişkisinde daha fazla destek sağlamıştır.

Sonuç olarak; ekokardiyografide hipertansiyon hastalarında KAH hastalığı artışı saptanmasına karşın, stabil KAH hastalarında HT'nin inflamatuar süreç üzerine additif etkisi gösterilemedi. Antihipertansif amaçlı ACE inhibitörleri ve ARB'lerinin kan basıncını düşürmede uygun ve etkili olduğu pek çok çalışmada gösterilmiştir. Ayrıca; bu grup ilaçların hipertansiyonlu hastalarda morbidite ve mortaliteyi konvansiyonel tedaviye (beta bloker ve diüretic benzer olarak azalttığı iki prospektif çalışmada (Captopril Prevention Project CAPPP, Swedish Trial in old Patients-2 with HypertensionSTOP-Hypertension II) kanıtlanmıştır (The CAPPP Group, 1990). Bunun yanı sıra kullanımının stabil $\mathrm{KAH}^{\prime} \mathrm{da}$ da inflamatuvar cevabı azaltabileceği şeklinde düşünülmektedir.

\section{Teşekkür}

Çalışmamızda bize emeği geçen klinik sahibine ve çalışma arkadaşlarıma, hayvan sahiplerine çok teşekkür ederim.

\section{Kaynaklar}

Bhagat K, Moss R, Collier J, Vallance P, 1996: Endothelial "stunning" following a brief exposure to endotoxin: a mechanism to link infection and infarction? Cardiovasc Res ;32 (5), 822-9.

Chang JA, Froelicher VF, 1994: Clinical and exercise test markers of prognosis in patients with stable coronary artery disease. Curr Probl Cardiol, 8 (3), 533-87.

Chrysohoou C, Pitsavos C, Panagiotakos DB, Skoumas J, Stefanadis C, 2004: Association between prehypertension status and inflammatory markers related to atherosclerotic

disease: The ATTICA Study. Am J Hypertens ;17(7):568-73.

Chung NA, Beevers DG, Lip G, 2004: Effects of losartan versus hydrochlorothiazide on indices of endothelial damage/dysfunction, angiogenesis and tissue factor in essential hypertension. Blood Pres ;13(3):183-9.

Felmeden DC, Blann AD, Spencer CG, Beevers DG, Lip GY, 2003: A comparison of flow-mediated dilatation and von Willebrand factoras markers of endothelial cell function in health and in hypertension: relationship to cardiovascular risk and effects of treatment: a substudy of the Anglo Scandinavian Cardiac Outcomes Trial. Coagul Fibrinolysis ;14(5):425-31.

Fu ML, 1995: Abnormal immune system and hypertension: where arewe? Ann Med ;27(6):671-4. 
Gage JE, Hess OM, Murakami T, Ritter M, Grimm J, Krayenbuehl HP, 1986: Vasoconstriction of stenotic coronary arteries during dynamic exercise in patients with classic angina pectoris: reversibility by nitroglycerin. Circulation ;73(5):865-76.

Gordon T, Kannel WB, 1971: Premature mortality from coronary heart disease. The framingham study. JAMA ;215(10):1617-25.

Higashi Y, Sasaki S, Nakagawa K, Matsuura H, Oshima T, Chayama K, 2002: Endothelial function and oxidative stress in renovascular hypertension. $N$ Engl J Med ;346(25):1954-62.

Hingorani AD, Cross J, Kharbanda RK, et al, 2000: Acute systemic inflammation impairs endothelium dependent dilatation in humans. Circulation ;102(9):994-9.

Maat MP, Haverkate F, Kluft C, 2000: Relationship between CRP and clinical course of unstable angina depends on assay method. Vascul Pharmacol ;39(3):113-5.

Martinez Amenós A, Buendia E, Carreras L, 1985: Humoral and cellular immunological abnormalities in hypertensive patients. J Clin Hypertens ;1(2):153-60.

Mc Carron RM, Wang L, Siren AL, Spatz M, Hallenbeck JM, 1994: Monocyte adhesion to cerebromicrovascular endothelial cells derived from hypertensive and normotensive rats. Am J Physiol ;267(6 Pt 2):2491-7.

Mc Eniery CM, Wilkinson IB, 2005: Large artery stiffness and inflammation. J Hum Hypertens ;19(7)507-9.
Nurnberger J, Keflioglu-Scheiber A, Opazo Saez AM, Wenzel RR, Philipp T, Schafers RF, 2002: Augmentation index is associated with cardiovascularrisk. J Hypertens ;20(12):2407-14.

Okamura T, Moriyama Y, Kadowaki T, Kanda H, Ueshima $H$, 2004: Non-invasive measurement of brachialankle pulse wave velocity is associated with serum C-reactive protein but notwith alphatocopherolin Japanese middle-aged male workers. Hypertens Res ;27(3):173-80.

Renaudin C, Bataillard A, Sassard J 1995. Partial transfer of genetic hypertension by lymphoid cells in Lyon rats. J Hypertens. 13(12 Pt 2):1589-92

Sieg-Dobrescu D, Burnier M, Hayoz D, Brunner HR, Waeber B, 2001: The return of increased blood pressure after discontinuation of antihypertensive treatment is associated with an impaired postischemic skin blood flow response. J Hypertens;19(8):1387-92

The CAPPP Group, 1990: The Captopril Prevention Project: a prospective intervention trial of angiotensin enzyme inhibition in the treatment of hypertension. J Hypertens, 8:985-990.

*Yazışma adresi: Mehmet İriadam

Harran Üniversitesi Veteriner Fakültesi Fizyoloji AD Eyyübiye Yerleşkesi, Şanlıurfa, Türkiye.

e-mail: miriadam@harran.edu.tr. 